http://dx.doi.org/10.1590/0104-07072017005970015

\title{
MANCHESTER TRIAGE SYSTEM IN PRIMARY HEALTH CARE: AMBIGUITIES AND CHALLENGES RELATED TO ACCESS
}

\author{
Danielle de Araújo Moreira1, Hanna Beatriz Bacelar Tibães², Renata Cristina Rocha \\ Batista ${ }^{3}$, Cecília Maria Lima Cardoso ${ }^{4}$, Maria José Menezes Brito
}

${ }^{1}$ M.Sc. in Nursing. Escola de Enfermagem, Universidade Federal de Minas Gerais (UFMG). Belo Horizonte, Minas Gerais, Brazil. E-mail: danimg12@yahoo.com.br

${ }^{2}$ M.Sc. in Nursing. Escola de Enfermagem, UFMG. Belo Horizonte, Minas Gerais, Brazil. E-mail: hannabacelar@gmail.com

${ }^{3}$ Nurse. Hospital das Clínicas, UFMG. Belo Horizonte, Minas Gerais, Brazil. E-mail: renatinhacrb@hotmail.com

${ }^{4}$ M.Sc. in Nursing. Escola de Enfermagem, UFMG. Belo Horizonte, Minas Gerais, Brazil. E-mail: cecilialimacardoso@yahoo.com.br

${ }^{5}$ Ph.D. in Nursing. Professor. Escola de Enfermagem, UFMG. Belo Horizonte, Minas Gerais, Brazil. E-mail: mj.brito@globo.com

\begin{abstract}
Objective: understanding ambiguities and challenges related to access after implementing the Manchester Triage System in primary health care.

Method: a qualitative study developed through semi-structured interviews with nurses, doctors and nursing technicians, totaling 22 professionals. The data were analyzed using the thematic content analysis method.

Results: the Manchester Triage System antagonistically interfered with access. In one aspect, an increase in waiting time, difficulty of the user being attended and scheduling of cases that are not classified as acute can be observed. In another aspect, service guarantee, open door service, receiving service in order of arrival and organizing spontaneous demand can be emphasized.

Conclusion: the study highlights the need to broaden discussions on the legitimacy of the Manchester Triage System in primary health care in view of its ambiguities and challenges regarding a guarantee of access in this area of care production.

DESCRIPTORS: Access to health services. Primary health care. Triage. Nursing. Unified Health System. User embracement.

\section{O SISTEMA DE TRIAGEM DE MANCHESTER NA ATENÇÃO PRIMÁRIA À SAÚDE: AMBIGUIDADES E DESAFIOS RELACIONADOS AO ACESSO}

\section{RESUMO}

Objetivo: compreender ambiguidades e desafios relacionados ao acesso, após a implantação do Sistema de Triagem de Manchester na atenção primária à saúde.

Método: estudo de abordagem qualitativa, desenvolvido por meio de entrevista semiestruturada com enfermeiros, médicos e técnicos de enfermagem, totalizando 22 profissionais. Os dados foram analisados por meio do método análise de conteúdo temática.

Resultados: o Sistema de Triagem de Manchester interferiu de forma antagônica no acesso. Em uma vertente, observa-se o aumento do tempo de espera, a dificuldade do usuário em ser atendido e o agendamento dos casos que não são classificados como agudos. Em outra vertente, ressalta-se a garantia do atendimento, a porta aberta do serviço, o fim do atendimento por ordem de chegada e organização da demanda espontânea.

Conclusão: o estudo destaca a necessidade de ampliar discussões sobre a legitimidade do Sistema de Triagem de Manchester na atenção primária à saúde, tendo em vista ambiguidades e desafios referentes à garantia de acesso neste espaço de produção do cuidado.

DESCRITORES: Acesso aos serviços de saúde. Atenção primária à saúde. Triagem. Enfermagem. Sistema Único de Saúde. Acolhimento. 


\section{EL SISTEMA DE TRIAGE DE MANCHESTER EN LA ATENCIÓN PRIMARIA EN SALUD: AMBIGUEDADES Y DESAFIOS RELACIONADOS AL ACCESO}

\section{RESUMEN}

Objetivo: comprender ambigüedades y desafíos relacionados con el acceso, después de la implantación del Sistema de Triage de Manchester en la atención primaria en salud.

Método: investigación cualitativa, que utilizó la entrevista semiestructurada con enfermeros, médicos y auxiliares de enfermería, totalizando 22 profesionales. Los datos fueron analizados por medio de análisis de contenido temático.

Resultados: el Sistema de Triage de Manchester interfirió de forma antagónica en el acceso. En una vertiente, se observa el aumento del tiempo de espera, la dificultad del usuario en ser atendido y el agendamiento de los casos que no son clasificados como agudos. Por otra parte, se resalta la garantía del atendimiento, la puerta abierta del servicio, con el fin de atender por orden de llegada y la organización de la demanda espontanea.

Conclusión: el estudio destaca la necesidad de ampliar discusiones sobre la legitimidad del Sistema de Triage de Manchester en la atención primaria en salud, teniendo en vista las ambigüedades y desafíos referentes a la garantía de acceso en este espacio de producción del cuidado. DESCRIPTORES: Accesibilidad a los servicios de salud. Atención primaria de salud. Triaje. Enfermería. Sistema Único de Salud. Acogimiento.

\section{INTRODUCTION}

In Brazil, access to health care is a universal right, and it is the duty of all federal bodies to subsidize the quality and comprehensiveness of the care provided to the population. In this sense, the decentralization proposed by the Brazilian Unified Healthcare System (SUS) has strengthened and expanded the assistance offered in municipalities, especially with the advent of primary health care (PHC) as an assistance model based on longitudinal care and broadening access, which integrates government policies and actions. With this, PHC began to be considered as a point of preferential healthcare, providing individuals, families and communities with access to essential healthcare. ${ }^{1}$

With the implementation of the National Primary Healthcare Policy in Brazil (PNAB), advances in the PHC organization have been numerous, both in relation to experiences as well as attempts in structuring at the municipal and regional levels.

Ministerial Ordinance number 1.654 established by the Ministry of Health in 2011, launched the National Program for Access and Quality Improvement in Primary Care (PMAQ) as a PNAB mobilization strategy for PHC qualification. This was viewed as an important inducer of changes in operating conditions and operation mode of Basic Health Units (UBS), aiming to increase access and qualification of care practices, management and participation. ${ }^{2-3}$

Despite the initiatives, some challenges need to be considered in order for PHC to be able to play its role as system organizer and healthcare coordinator. ${ }^{2}$ Among these, it is to overcome the fragmentation of supplying actions and services so that it can respond to the health needs of the population, who undergo changes related to demo- graphic, epidemiological and nutritional transition, thus contributing to the increasing demand in the health area and, therefore, requiring adjustments in policies and SUS actions..$^{3-4}$

In response to this demand, the Healthcare Network (RAS) represents an important restructuring strategy to overcome the fragmentation in the way care is delivered and health management. ${ }^{5}$ RAS aims to offer continuous and comprehensive care to the population and must be coordinated by the PHC in order to provide services at the right time, place, cost and quality, and also in a humanized and equitable way. ${ }^{6}$

All the points of attention that make up the RAS must be aimed at improving the health situation, and for it to have principles and technological devices that are consistent with the objectives to be achieved. Regarding PHC, it should consolidate itself as a preferred contact space between the population and professionals, focusing on longitudinal care and practices that enable health promotion and disease prevention. ${ }^{7}$

By reformulating the National Policy of Emergency Care in 2011, PHC began to integrate the provision of care to users with urgent/emergent cases in their care practices. ${ }^{8}$ In this context, in 2012, the State Secretary of Health of Minas Gerais (SES-MG) opted to implement the classification of risk using the Manchester Triage System (MTS) in all health care units in order to standardize the screening criteria and to meet spontaneous demand in a shorter time, in addition to integrating health services and reducing the fragmentation of the care network. ${ }^{9}$

The risk classification systematized by the MTS determines patterns for emergency response by replacing the traditional organization model of demands. ${ }^{10}$ However, for this system to effectively guarantee access and satisfactorily respond to the needs of PHC users, it is necessary for practitioners 
to use resources, skills and attitudes to ensure qualified care and reference and counter-reference. ${ }^{11}$

Studies by the Brazilian Group of Risk Classification (GBCR) show that the use of MTS has achieved the objective of establishing waiting time and eliminating service by order of arrival, organizing the care network with rationalization, resolution, equity of access and humanization of health services. ${ }^{12}$ However, it is assumed that the use of MTS in the PHC has affected user assistance and access. In view of the above, it is asked: what are the ambiguities and challenges related to access after implementing the Manchester Triage System in primary health care?

From the above outlook, this study was developed with the aim of understanding ambiguities and challenges related to access after implementing the Manchester Triage System in primary health care.

\section{METHOD}

This is a case study using a qualitative, exploratory-descriptive approach. The choice of method is justified as this is a contemporary phenomenon inserted in a certain real life context. ${ }^{13}$

The study incorporated all the health centers of a city located in the metropolitan area of Belo Horizonte, Minas Gerais, totaling seven units. The choice for this scenario is justified by the fact that the municipality has already implemented the MTS in all the health centers that comprise it, with each one having a family health team.

Participants were nurses in nursing management or related functions, nursing technicians and physicians. The selection criteria for the sample composition were as follows: the total number of professionals; being part of the aforementioned PHC staff; and in relation to the nurses, being responsible for applying the MTS.*

From the total of 26 selected participants, 22 were interviewed; among them, seven nurses (71.4\% female), four physicians (75\% male) and 11 nursing technicians (100\% female). Four interviews were not carried out; two with doctors due to unit transfer, and two with nursing technicians (one being due to refusal and another for successive missed appointments).

Data were collected between April and May 2014 through a semi-structured interview script. The interviews were individually conducted in the health centers, with an average duration of fifty minutes. All the interviews were recorded on two electronic audio devices, fully transcribed and analyzed using thematic content analysis. ${ }^{14}$

Data analysis was performed around three chronological poles, being: pre-analysis, material exploration and treating the results. ${ }^{14}$ The pre-analysis phase was based on organizing the material followed by transcription, which made it possible to order the interviews according to the semi-structured script questions. Next, an exhaustive reading was conducted, which allowed for defining central themes and comparable units. In the following phases, material exploration was conducted with more acumen and the results were treated in a significant and valid way. It was possible to make inferences and interpretations of the data after concluding these steps, correlating them with the study objectives. ${ }^{14}$

The study was approved by the Research Ethics Committee of the Universidade Federal de Minas Gerais (CAAE: 25923013.4.0000.5149) and by the Municipality inserted in the study scenario by a letter of agreement. Participants signed the Clear and Informed Consent Form. In order to guarantee their anonymity, participants are referred to according the following codes: nurses $(\mathrm{N})$, physicians $(\mathrm{Ph})$ and nursing technicians $(\mathrm{NT})^{*}$, and numbered according to the interview sequence.

\section{RESULTS}

Data analysis made it possible to list the following analytical categories: Dimensions of access from health professionals' point of view and Ambiguities of the Manchester Triage System in access to primary health care.

\section{Dimensions of access from health professionals' point of view}

The concept of access has been identified in this study as encompassing interrelated organizational, social and geographical dimensions. The organizational dimension is mainly due to the possibility of the user having access to all the resources available at the unit.

Well, I think it's the fact that they arrive at the unit and are attended by everybody, not only by the nursing team, but by the health agents, by the reception; they have access to the whole unit, all of its functioning, how the unit works, and what are their rights and duties. This is what I mean by access (NT1).

* In Brazil, nursing is divided into three categories: nurse, nursing technicians and nursing auxiliaries, being the highest level is a nurse, followed by technicians and auxiliaries. Translator's note. 
It should be noted that in addition to pointing out access as the possibility of the user arriving at the unit, NT1 also highlights teamwork, which is considered essential and expected in terms of PHC care.

With regard to the social dimension, the importance of the population understanding the information transmitted by the team was especially mentioned:

[...] I think there is still much to be desired, especially regarding information, I think the information is not very clear right? So, I believe that most users who come, the majority of them are older, they are seniors, so if he [the professional] does not make it very clear, most users leave without actually knowing what is being used, I think the information has to be clear (NT9).

[...] and the patients, some are laymen, right? Sometimes they just want to get a referral, so they come to us without knowing where to go to get a referral (NT11).

In relation to the geographic dimension, access is understood as the user's commute to the health service, referring to the concept of geographical accessibility and territoriality.

I think access here is great for them. Because this place here is a good location, it's not far away [...] (N5).

[...] Territory access, right? Access as a whole (N2).

However, ease of access to reach PHC was not considered a determining factor for resolving the health need presented by the user.

[...] there are almost eight thousand inhabitants here in the region for only one doctor, for one (health) team here at this center. It's hard to think that everyone will have the same access to good care this way, it's a matter of numbers, it's a bit difficult. [...] (Ph4).

\section{Ambiguities of the Manchester Triage System in access to primary health care}

Participants pointed out ambiguities of the MTS in accessing PHC. From the perspective of the professionals, the main justifications presented for negative interferences were: users lack of knowledge regarding the risk classification implementation by the MTS; work overload placed on nurses; an increase in waiting time for users to access the service; and the priority of care for acute cases in PHC:

[...] the patient does not yet have information about the Manchester System, so they think if they have to wait because I am triaging a severe case that I'm making their life difficult, so sometimes it gets in the way a bit, but this is also a matter of management, because everything is the responsibility of nurses, so in fact the patient gets tired of waiting, right, for a reason! (N1)

[...] in fact, now I don't see how it [the MTS] helps in the health center service, because the patients in their great majority are control patients, right, they are not severe, and the severe ones I was going to see regardless of Manchester or not, and the patient who was yellow or red I was going to give them priority service and send them to the [urgency] unit. Now, the other [non-urgent] patients will be scheduled because it is the reality (N6).

Regarding the justifications presented by the participants about the positive interference of the MTS in the access of the users, the most notable were disruption in the service by arrival order and the guarantee of access to the service:

[...] before we had to give out numbers, and those who arrive early are rewarded, so with Manchester, if the patient gets here at any time and they are classified as urgent, they will be attended just like those that arrived at six in the morning. That's the way it is, it's fairer, right? (N4).

[...] It came to makes things easier, because from the moment you have a priority that is on paper, that you have to adhere to as well as comply to, then access will be more accurate, guaranteed (N2).

It facilitated access. The Manchester has opened the doors, Basic healthcare is the user's entrance, and that is what they are seeing, but I think they should see the professionals' side, those who are here and who get sick from so much pressure, so many things like this (N3).

Among the participants, NT3, NT4, NT8 and N7 did not report positive nor negative points regarding the MTS implementation and access to PHC. Arguments by NT3 and NT4 were based on the fact that, despite implementation of the protocol, the demands continue to be forwarded and resolved:

[...] because things that are really not from here are going to be forwarded, right? Either to the polyclinic, or to a specialized center, and those who require a clinician, a gynecologist, or a pediatrician we solve right here (NT3).

[...] regardless of how they get here [the patients], when they go through triage/screening, regardless of it being a momentary complaint or not, we will try to solve it (NT4).

Although they did not indicate positive nor negative interferences, two testimonies stand out for mentioning the fragility of the MTS in PHC. For NT8, the protocol is limited in comprehensive care of the demands and user's needs. N7 also reported that the use of the MTS hinders access, since the protocol does not require historical 
registration of the users, which is essential for outlining care plans.

I do not believe it has interfered because in fact, one way or another they would have to talk to the nurse and whatever they say [patient] the nurse will put on the record? And the Manchester will simply classify it. Of course there are some patients who have complaints that the Manchester does not classify, where the care has to be today (NT8).

No, it does not interfere with access, it only hinders this access, I think I found the ideal word, you know? In the primary unit, the patient's access has to be more flexible, we have to understand the patient's history to get a more organized access for the patient, get it? For this point, I think Manchester hinders this procedure too much. At no time does it require a history, to look at a medical record; because it is not a system for attending medical records (N7).

\section{DISCUSSION}

Access to health services is considered the first phase to be overcome by the user in the search for satisfaction of a need or service to solve their problems. ${ }^{15}$ Thus, universal access directly depends on the involvement of professionals in the different services. ${ }^{16}$ Despite the permanent concern with access to health, conceptualizing it is still a challenge. ${ }^{17}$ For the purpose of the present study, the conceptual approach of access was used, taking into account the organizational, social and geographical dimensions. ${ }^{18}$

Regarding the organizational dimension, which is related to the possibility of the user accessing the resources available in the unit, NT1 refers to teamwork as a way of consolidating health comprehensiveness, directly impacting the quality and improvement of access offered to the user. ${ }^{19}$

The social dimension is linked to relational aspects. Data from this study revealed the importance of effective communication between the health team and the population. It is emphasized that communication is essential for professionals to have a holistic view of the user and community with a view of transforming practice. ${ }^{20}$

Under this communicational aspect, we highlight the potential of PHC professionals to act in the community, ${ }^{21}$ reinforcing the importance of social participation in broadening the bond and the autonomy of users, contributing to the exchange of knowledge, humanization and health education.

However, not all professionals are qualified to develop health education as an innovative and transformative practice, promoting dialogue and a broader conception of health. ${ }^{22}$ This reality reinforces the traditional model of professional-user information transmission, which limits evaluating the impacts of the developed actions and hinders the participation of the subject in the health-disease-care process.

Regarding the geographical aspect as a dimension of access, it should be emphasized that it is related to geographic accessibility and territorialisation. ${ }^{15}$ Data analysis allows us to understand that the proximity of the health center to the users' residence is a favorable factor, directly influencing access quality.

Although expansion of the primary network has contributed to improving geographical accessibility, a disproportion between supply, service capacity and demand has been verified in some places. Thus, the classic model of healthcare for spontaneous demand remains due to a limitation of comprehensive care and the fragility of the regionalized reference and counter-reference network, ${ }^{23}$ which implies a fragile construction of health practices in which the real needs expressed by users are not met. $^{24}$

The ability of users to access all points of RAS is paramount to ensuring continuity of care and decentralization, dynamism and flexibility, aiming at effectiveness in decisions and contributing to the improvement of the assistance offered in the municipalities. ${ }^{19}$ In this aspect, PHC has a primordial function for being considered the care coordinator.

Concerning interference by the MTS to access PHC, the participants mentioned negative and positive aspects. Regarding the negative aspects, n6 reported the priority of care to users in acute conditions. Therefore, it is essential for professionals to ensure that care for urgent and emerging cases do not detract from the attention given to chronic or social cases that require resources and follow-up by all those involved in the care process. In this way, articulation between the various services of the care network is fundamental to drive the care flows, comprehensiveness and to guarantee safe access to the necessary technologies according to the proposal of each point of care. ${ }^{19}$

The positive aspects indicated that the MTS has contributed to a disruption of first-come, firstserved and guaranteed access to service. Risk classification as a new service logic in the PHC allows for the practice of equity, producing access to the system and guaranteeing assistance. ${ }^{25}$ In addition, 
the MTS consists of a dynamic process that aims to identify users and their health needs according to the potential of risk, in order to offer immediate care through fast and effective care. ${ }^{26}$

Despite expressing positive aspects, N3 reported that the workload arising from the use of MTS was a factor in generating pressure and illness in the healthcare team. Receiving users represents significant space in nurses' working time, in addition to it occurring in a punctual way, which constitutes an action far from the proposal of the nursing care since this should be prioritized in the comprehensive care of human beings. ${ }^{27}$ Implementation of the MTS was reflected by changes in the daily work of the professionals, because in addition to interfering in the activities already developed by nurses, it contributed to an increase in their assignments/duties. This fact reinforces the impact on daily practices since a single professional category is responsible for screening users and performing other activities recommended for the PHC. ${ }^{28}$

Data analysis showed that some participants did not position themselves on either the positive or negative aspects of the MTS in accessing PHC, since users continued to be attended and referenced for other services according to their presented health need.

It can be noted that when users with acute complaints seek care and the demand exceeds the PHC's resolving capacity, the user's reference to other health services must be ensured according to RAS's proposal to meet demand with accountability and resoluteness.

Regarding weaknesses of the MTS in the PHC, N7 emphasized that this form of triage hinders user access to the service. User service at this point in RAS demands a welcoming attitude by the professionals, being essential to establish a relationship between the registered complaint and the user's life history. Adherence to treatment and access are thus facilitated by the relationship between the patient and the professional, having family and community as its focus. ${ }^{29-30}$

A logic of access based on risk classification can refer to a lack of reception and indifference by professionals to users' suffering when objectively dealing with subjective aspects. Thus, the use of MTS in the PHC can reveal a bureaucratic rationality that puts the subject's autonomy at stake in its health/disease/care process. ${ }^{25}$ When used as a single source of response to user needs, MTS becomes insufficient because it does not encompass subjective, affective, social, or cultural aspects.
However, access may be hindered by use of the MTS, considering that the dialogue is weakened and there is a closer link between the health unit and the community. ${ }^{28}$

It is important to emphasize the importance of putting the principles of the current care model into practice, ensuring relevant aspects such as qualified listening, continuity of care and the holistic view of users. These are the principles that will allow for total or partial resolution of the presented needs, which may require interdisciplinary actions involving the health team.

This study ratified that inserting the nurse into the care during and after risk classification requires choices and attitudes that reinforce their professional autonomy, not being limited to the registration and the classification of the user through discriminators, but deliberating on their actions in an ethical and responsible manner. In this way, when the professional is able to know their reality and articulate their managerial knowledge to the care provided to the users, this can transform their practice into better strategies to fine-tune the processes and add more and more quality to the provided care. ${ }^{31}$

It should be emphasized that the MTS can be configured as an opportunity to enable humanized reception, offering support for comprehensive, continuous and safe care. However, the use of this tool in the PHC requires constant analysis, considering that the protocol had a positive and negative impact on the user's access to PHC. Thus, organizational demands need to be identified and studied by managers, professionals and users, so that PHC becomes, in fact, a more appropriate space for the care of users and their families, focusing on their realities and needs. ${ }^{32}$

This study presents limitations because it considers a specific reality, which makes it impossible to generalize its results. However, its importance lies in the possibility of compelling further research on the MTS in the context of PHC.

\section{CONCLUSION}

With regard to access, we noticed that the participants discussed the organizational, social and geographical dimensions, respectively pointed out by the possibility of the user having access to all available resources in the unit, by the importance of the population understanding the information transmitted by the team, and by the user's commute to the healthcare service. 
There were both negative and positive interferences of the protocol regarding ambiguities and challenges related to access after implementing the MTS in the PHC. In relation to the first, we highlight the lack of knowledge in performing the risk classification by the MTS; work overload of nurses; extended waiting time for users to access the service; and the priority of serving acute cases in the PHC. The positive interference refers to the disruption of first-come-first-served service and the guarantee of access to the service.

In addition, some of the participants did not indicate positive or negative interferences after implementing the MTS in PHC. The reports demonstrated that the protocol hinders access, and limits comprehensive care to the demands and the needs of the users, but nevertheless demands continue to be addressed and resolved.

The findings of this study may be related to the recent implementation of the MTS in PHC of Minas Gerais, and the divergence of opinions reinforces the importance of expanding discussions about the guarantee of access at this point of care. Therefore, it is necessary for professionals to reflect on their practice so as not to allow their actions to focus on bureaucratic rationality.

\section{REFERENCES}

1. Sousa MF, Hamann EM. Programa Saúde da Família no Brasil: uma agenda incompleta? Ciênc Saúde Colet. 2009;14(Suppl 1):1325-35.

2. Fausto MCR, Giovanella L, Mendonça MHM, Seidl H, Gagno J. A posição da Estratégia Saúde da Família na rede de atenção à saúde na perspectiva das equipes e usuários participantes do PMAQ-AB. Saúde debate. 2014 Out;38 (spe):13-33.

3. Ministério da Saúde (BR). Portaria $n^{\circ}$ 1.654, de 19 de julho de 2011. Institui no âmbito do Sistema Único de Saúde, o Programa Nacional de Melhoria do Acesso e da Qualidade da Atenção Básica (PMAQ-AB) e o Incentivo Financeiro do PMAQ-AB, denominado Componente de Qualidade do Piso de Atenção Básica Variável - PAB Variável. Diário Oficial da União. Brasília (DF): MS; 2011.

4. Lavras C. Atenção primária à saúde e a organização de redes regionais de atenção à saúde no Brasil. Saúde Soc. $2011 ; 20(4): 867-74$.

5. Arruda C, Lopes SGR, Koerich MHAL, Winck DR, Meirelles BHS, Mello ALSF. Health care networks under the light of the complexity theory. Esc Anna Nery. 2015;19(1):169-73.

6. Mendes EV. As redes de atenção à saúde. Ciênc Saúde Colet. 2010;15(5):2297-305.

7. Starfield B. Atenção Primária: equilíbrio entre necessidades de saúde, serviços e tecnologia. Brasília (DF): UNESCO/Ministério da Saúde; 2002.
8. Ministério da Saúde (BR)Portaria $n^{\circ} 1.600$, de 07 de julho de 2011. Reformula a Política Nacional de Atenção às Urgências e institui a Rede de Atenção às Urgências no Sistema Único de Saúde (SUS). Diário Oficial da União. Brasília: MS; 2011.

9. Ministério da Saúde (BR)Secretaria de Estado de Saúde de Minas Gerais (SES). SES promove reunião para discutir Protocolo de Manchester [online], 2012 [cited, 2015 May 14]. Disponível em: http://www. saude.mg.gov.br/component/gmg/story/3548-sespromove-reuniao para $\% 20$ discutir-protocolo-demanchester-sesmg.

10. Shiroma LMB, Pires DEP. Classificação de risco em emergência - um desafio para as/os enfermeiras/os. Enferm Foco. 2011; 2(1):14-17.

11. Lumer S, Rodrigues PHA. O papel da saúde da família na atenção às urgências. Rev APS. 2011;14(3):289-95.

12. Grupo Brasileiro de Classificação de Risco. Sistema Manchester de Classificação de Risco. Manchester Triage Group; 2010.

13. Yin RK. Estudo de caso: planejamento e métodos. 4 ed. Porto Alegre: Bookman; 2010.

14. Bardin L. Análise de conteúdo. 4 ed. Lisboa: 70 edições; 2009.

15. Assis MMA, Jesus WLA. Acesso aos serviços de saúde: abordagens, conceitos, políticas e modelo de análise. Ciênc Saúde Colet. 2012; 17(11):2865-75.

16. Cassiani SHB. Strategy for universal access to health and universal health coverage and the contribution of the International Nursing Networks. Rev Latino-Am. Enfermagem. 2014; 22(6):891-92.

17. Levesque JF, Harris MF, Russell G. Patient-centred access to health care: conceptualising access at the interface of health systems and populations. Inter J Equity Health. 2013; 12:18.

18. Souza MSPL. Fatores associados ao acesso geográfico aos serviços de saúde por pessoas com tuberculose em três capitais do Nordeste brasileiro. Cad Saúde Pública. 2015;31(1):111-20.

19. Souza ECF, Vilar RLA, Rocha NSPD, Uchoa AC, Rocha PM. Acesso e acolhimento na atenção básica: uma análise da percepção dos usuários e profissionais de saúde. Cad. Saúde Pública; 2008; 24 (Suppl 1):100-10.

20. Araujo MB, Rocha PM. Trabalho em equipe: um desafio para a consolidação da estratégia de saúde da família. Ciênc Saúde Colet. 2007; 12(2):455-64.

21. Queiroz RD, Silva ASS, Silva WO, Lima LT, Melo KM, Oliveira CG. Conhecimento da população do bairro farolândia sobre o Programa Saúde da Família (PSF). Rev APS. 2013;16(1):83-89.

22. Frutuoso MFP, Mendes R, Rosa KRM, Silva CR.de C. Gestão local de saúde em território de vulnerabilidade: motivações e racionalidades. Saúde debate. 2015;39(105):337-49.

23. Oliveira LC, Avila MMM, Gomes AM.de A, Sampaio MHL.de M. Participação popular nas ações de 
educação em saúde: desafios para os profissionais da atenção primária. Interface (Botucatu). 2014; 18(suppl.2):1389-400.

24. Amorim ACCLA, Assis MMA, Santos AM, Jorge MSB, Servo MLS. Práticas da equipe de saúde da família: orientadoras do acesso aos serviços de saúde? Texto Contexto Enferm. 2014 Out-Dez; 23(4):1077-86.

25. Speroni AV, Menezes RA. Os sentidos do Acolhimento: um estudo sobre o acesso à atenção básica em saúde no Rio de Janeiro. Cad Saúde Colet. 2014; 22(4):380-5.

26. Silva PM, Barros KP, Torres H. Acolhimento com classificação de risco na Atenção Primária: percepção dos profissionais de enfermagem. Rev Min Enferm. 2012; 16(2): 225-31.

27. Costa PCP, Garcia APRF, Toledo VP. Acolhimento e cuidado de enfermagem: um estudo fenomenológico. Texto Contexto Enferm, 2016; 25(1):1-7.
28. Moreira DA, Tibães HBB, Batista, RCR, Cardoso CML, Santos C.da S, Brito MJM. Manchester Screening System in Primary Health Care: a new hosting way? International Arquives of Medicine. 2015; 8(261): 1-9.

29. Sanchez RM, Ciconelli RM. Conceitos de acesso à saúde. Rev Panam Salud Publica. 2012; 31(3):260-8.

30. Barbosa SP, Elizeu TS, Penna CMM. Ótica dos profissionais de saúde sobre o acesso à atenção primária à saúde. Ciênc Saúde Colet. 2013; 18(8):2347-57.

31. Lanzoni GMM, Meirelles BHS, Erdmann AL, Thofehrn MB, Dall' Agnol CM. Ações/interações motivadoras para liderança do enfermeiro no contexto da atenção básica à saúde. Texto contexto Enferm. 2015; 24(4): 1121-9.

32. Duarte ED, Silva KL, Tavares TS, Nishimoto CLJ, Silva PM, Sena RR. Cuidado à criança em condição crônica na atenção primária: desafios do modelo de atenção à saúde. Texto Contexto Enferm. 2015; 24(4):1009-17. 